\title{
Effect of Vehicles on Release of Meloxicam from Various Topical Formulations
}

\author{
Gülgün Yener* Özlem Dal and Melike Üner
}

Istanbul University, Faculty of Pharmacy, Department of Pharmaceutical Technology, Beyazit 34116 Istanbul, Turkey

\begin{abstract}
This article evaluates the effect of various vehicles $(\mathrm{O} / \mathrm{W}, \mathrm{W} / \mathrm{O}$ and two $\mathrm{W} / \mathrm{O} / \mathrm{W}$ emulsions and a hydrogel) on meloxicam release. One of $\mathrm{W} / \mathrm{O} / \mathrm{W}$ emulsions was named $\mathrm{W} / \mathrm{O} / \mathrm{W}-\mathrm{C}$ containing Carbopol $^{\circledR} 934$ as a gelling agent in its outer aqueous phase. Release of drug through cellulose acetate membrane was studied by using Franz-type diffusion cells. Hydrogel formulation gave the highest release with a significant difference followed by $\mathrm{W} / \mathrm{O} / \mathrm{W}, \mathrm{O} / \mathrm{W}, \mathrm{W} / \mathrm{O} / \mathrm{W}-\mathrm{C}$ and $\mathrm{W} / \mathrm{O}$ emulsions. Increase in amount of oil phase resulted in slower drug release strictly indicating importance of lipophility of vehicle on release of lipophilic drugs like MX. Incorporation of MX in hydrogel increased the released amount by up to 20 times when compared with the other formulations. Increase in viscosity of the formulations was also followed the same order. Release study was performed by using UV spectroscopy. Furthermore, the determination method of MX was validated through the following performance criteria: linearity, intra-day and inter-day precision, accuracy, specifity and recovery. This method was proved as precise and accurate determination of MX in multi-component pharmaceutical preparations besides colorimetric methods.
\end{abstract}

Keywords: Meloxicam, poorly water-soluble drug, drug release, multiple emulsion, assay validation.

\section{INTRODUCTION}

Non-steroidal antiinflammatory drugs (NSAID's) are widely used to provide effective therapy in patients with chronic rheumatic disorders. However, their oral administration have been associated with a number of gastrointestinal (GI) disorders which can reduce patient compliance. Meloxicam (MX) is a preferential COX-2 inhibitor with strong anti-inflammatory activity. It is practically insoluble in water and has a larger onset of action. Its prolonged use causes side effects like GI perforations, ulcerations and even bleeding [1-3].

Researchers have been trying to overcome GI side effects by the topical delivery of NSAIDs. Skin has been shown to be a suitable delivery route for drugs formulated topically during the past few years. Ketoprofen, naproxen, tenoxicam and celecoxib can be counted among these [4-6]. It has been also reported that NSAID's promote local analgesia when topically applied [7]. In addition, a recent study has shown that topical application of cyclooxygenase inhibitors suppresses UVB mediated cutaneous inflammation. Therefore, topical application of MX seems to have another important role inhibiting UVB mediated inflammation as well as its systemic anti-inflammatory effects without major GI side effects [8].

The most common pathway for absorption of lipophilic drugs is transcellular passive diffusion. However, drug molecules encounter various types of resistance such as membrane and diffusion resistance when they permeate through biological membranes. Therefore, there is a need for an in vitro model that mimics these physiochemical properties of biological membranes and screening of passive drug

\footnotetext{
*Address correspondence to this author at the Istanbul University, Faculty of Pharmacy, Department of Pharmaceutical Technology, Beyazit 34116 Istanbul, Turkey; Tel: + 9021244002 91; Fax: + 9021244002 52;

E-mail: gulyen@superonline.com
}

diffusion. For this aim, artificial membranes can be used during development of pharmaceutical formulations and finished topical dosage forms [9]. Hereby, in vitro models have also been useful as basic systems for comparing various excipients and vehicles including creams and ointments on drug availability since physicochemical properties of vehicles strongly influence drug release. There are also number of successful prediction models using molecular properties. They are simple test models for actives in good correlation with in vivo results [10-12]. In this study, we investigated the influence of different topical vehicles on the release of MX. For this aim, we incorporated MX in various optimized topical formulations; $\mathrm{O} / \mathrm{W}, \mathrm{W} / \mathrm{O}$ and two $\mathrm{W} / \mathrm{O} / \mathrm{W}$ emulsions and a hydrogel [13]. Release of MX from these formulations through cellulose acetate (CA) membrane as an artificial one was investigated by using Franz-type diffusion cells and results were statistically compared. Quantification of MX was made by an easy spectrophotometric method. Validation of the method was performed to demonstrate its rapidity, reproducibility and high sensitivity.

\section{MATERIALS AND METHODS}

\section{Materials}

Meloxicam (MX) was kindly supplied from Bilim İlaç Sanayii A.Ş. (Istanbul, Turkey). Abil ${ }^{\circledR}$ EM 90 was donated by Goldschmidt (Germany). Tween ${ }^{\circledR} 80$ (Henkel, Germany) and Carbopol ${ }^{\circledR} 934$ (BF Goodrich Co., USA) were provided as gifts. All the other chemicals were of analytical grade.

\section{Methods}

\section{Preparation of Topical Formulations}

\section{$\mathrm{O} / \mathrm{W}$ and $\mathrm{W} / \mathrm{O}$ Emulsions}

Compositions of both $\mathrm{W} / \mathrm{O}$ and $\mathrm{O} / \mathrm{W}$ emulsions are shown in Table 1. In case of $\mathrm{W} / \mathrm{O}$ emulsion, oil phase 
containing MX, cethyl alcohol, parafin, glyceryl monostearate and beeswax was heated up to $70 \pm 2^{0} \mathrm{C}$ in a water bath. Then, it was added to the aqueous phase composed of propylene glycol and water at the same temperature under stirring at $800 \mathrm{rpm}$ by using a propeller stirrer (IKA Labortechnik RW 20). Emulsion was continued stirring until cooling down to room temperature.

Table 1. Composition (w/w \%) of the Formulations

\begin{tabular}{|c|c|c|}
\hline Formulation & Compositi & \\
\hline $\begin{array}{c}\text { W/O } \\
\text { Emulsion }\end{array}$ & $\begin{array}{l}\text { MX } \\
\text { Cethyl alcohol } \\
\text { Liquid parafin } \\
\text { Glyceryl monostearate } \\
\text { Beeswax } \\
\text { Propylene glycol } \\
\text { Distilled water }\end{array}$ & $\begin{array}{c}2.0 \\
2.94 \\
49.5 \\
2.97 \\
7.92 \\
21.78 \\
13.86\end{array}$ \\
\hline $\begin{array}{c}\mathrm{O} / \mathrm{W} \\
\text { Emulsion }\end{array}$ & $\begin{array}{l}\text { MX } \\
\text { Cethyl alcohol } \\
\text { Liquid parafin } \\
\text { Propylene glycol } \\
\text { Sodium lauryl sulphate } \\
\text { Distilled water }\end{array}$ & $\begin{array}{c}2.0 \\
19.50 \\
19.50 \\
11.76 \\
0.98 \\
46.26\end{array}$ \\
\hline \multirow{2}{*}{$\begin{array}{c}\text { W/O/W } \\
\text { Emulsions }\end{array}$} & $\begin{array}{l}\text { W/O/W Emulsion: } \\
\text { Primary W/O emulsion (PE): } \\
\text { MX } \\
\text { Liquid parafin } \\
\text { Abil }^{\circledR} \text { EM90 } \\
\text { Magnesium sulphate } \\
\text { Distilled water } \\
\text { Outer phase: } \\
\text { Tween }^{\circledR} 80 \\
\text { Distilled water }\end{array}$ & $\begin{array}{c}2.0 \\
18 \\
4 \\
0.7 \\
75.3 \\
\\
16 \\
4\end{array}$ \\
\hline & $\begin{array}{l}\text { W/O/W-C Emulsions: } \\
\text { Primary W/O emulsion (PE): } \\
\text { MX } \\
\text { Liquid parafin } \\
\text { Abil }^{\circledR} \text { EM90 } \\
\text { Magnesium sulphate } \\
\text { Distilled water } \\
\text { Outer phase: } \\
\text { Tween }{ }^{\circledR} 80 \\
\text { Carbopol }^{\circledR} 934 \\
\text { Distilled water }\end{array}$ & $\begin{array}{c}2.0 \\
18 \\
4 \\
0.7 \\
75.3 \\
\\
16 \\
0.32 \\
4\end{array}$ \\
\hline Gel & $\begin{array}{l}\text { MX } \\
\text { Carbopol }^{\circledR} 934 \\
\text { Distilled water }\end{array}$ & $\begin{array}{c}2 \\
0.5 \\
97.5\end{array}$ \\
\hline
\end{tabular}

$\mathrm{O} / \mathrm{W}$ emulsion was prepared in the same manner by incorporation of sodium lauryl sulphate into aqueous phase.

\section{W/O/W Emulsions}

Multiple emulsion was obtained by two step process: In the first step, the primary $\mathrm{W} / \mathrm{O}$ emulsion containing $\mathrm{MX}$ in oil phase was prepared by using the propeller stirrer at a higher temperature $\left(80^{\circ} \mathrm{C} \pm 1\right)$ and stirred at $1500 \mathrm{rpm}$ for 15 minutes and then at $800 \mathrm{rpm}$ for 15 minutes. In the second step, the primary emulsion was incorporated slowly into an aqueous phase containing Tween $^{\circledR} 80$, a hydrophilic surfactant at room temperature while the system was stirred at a low speed (500 rpm) for 45 minutes until the formation of the multiple emulsion (Table $\mathbf{1}$ ).

\section{Hydrogel}

Carbopol $^{\circledR} 934$ was added to $70 \%$ of total water content of the formulation (Table 1) and it was kept over night at room temperature. Triethanolamine solution in water $(\mathrm{w} / \mathrm{w}$, $50 \%$ ) was used to provide proper gelation at $\mathrm{pH}$ 7.5. MX was dispersed in water by using the propeller stirrer at 500 rpm for 10 minutes. Then, MX dispersion was added to the Carbopol gel by stirring at the same rpm for 15 minutes.

\section{Viscosity Measurements}

Viscosity of the formulations were tested at room temperature using a Brookfield DV II viscometer (Germany) equipped with TF Helipath spindle at the first day after production date. Measurements were made at $100 \mathrm{rpm}$ in three replicates and viscosity values were recorded as centipoise $(\mathrm{cP})$.

\section{Validation of the Spectrophotometric Analysis}

Phosphate buffer solution at $\mathrm{pH} 7.4$ (PBS) was decided to be used as the receptor phase in diffusion experiments of MX through artificial membrane. For this reason, the analytical method for quantification of MX was previously validated and verified for linearity, intra-day and inter-day precision, accuracy, recovery and specifity. Each study was replicated 6 times [14].

\section{Linearity}

The linearity of the method was evaluated by linear regression analysis. $2,4,6,8,10$ and $12 \mu \mathrm{g} \mathrm{mL} \mathrm{m}^{-1}$ standard MX solutions in PBS were prepared by proper dilutions of a $1000 \mu \mathrm{g} \mathrm{mL}^{-1}$ stock MX solution with PBS. Absorbance of standard solutions was measured using a UV spectrophotometer (Shimadzu UV-Visible Spectrophotometer, UV-1601) at $272 \mathrm{~nm}$. The calibration curves were constructed by plotting concentration versus absorbance using linear regression analysis.

\section{Precision and Accuracy}

Intra-day and inter-day precision and the accuracy of the method were calculated from data obtained during a 5-day validation. The precision of the method was determined by intra-day repeatability and inter-day intermediate precision. 3 MX solutions in PBS (2, 4 and $6 \mu \mathrm{g} \mathrm{ml}^{-1}$ ) was prepared by proper dilutions of the stock MX solution $\left(1000 \mu \mathrm{g} \mathrm{mL}^{-1}\right)$ six times on the same day. Intermediate precision was assessed by comparing the assays on different days ( 5 days, $n=3$ at each concentration). Precision was expressed as the relative standard deviation (R.S.D., \%). Accuracy was expressed as the mean relative error (R.M.E., \%).

\section{$\underline{\text { Recovery }}$}

The recovery of the method was assayed using the standard addition technique by adding a known amount of standard at four different levels to the pre-analysed sample. The percentage recovery was calculated from the amount of 
drug found. For this purpose, the following equation was used,

$$
\text { Recovery }(\%)=\left(C_{t}-C_{u}\right) / C_{a} \times 100
$$

where $C_{t}$ is the total concentration of the analyte found, $C_{u}$ concentration of the analyte present the formulation, $C_{a}$ is the concentration of the pure analyte added to the formulation.

\section{Specifity}

Specifity of the method was also investigated for indicating that the constituent in the formulations did not interfere quantification of MX. For this aim, formulations represented in Table 1 were prepared without MX incorporation and the study was performed for each formulation. $0.5 \mathrm{~g}$ of formulation was weighed into a $25 \mathrm{~mL}$ volumetric flask. $10 \mathrm{~mL}$ PBS was added and the mixture was homogenized in an ultrasonic bath for 15 minutes. The mixture was diluted to $25 \mathrm{~mL}$ with additional PBS and filtered through blue ribbon filter paper $\left(S \& S^{5893}\right) .1 \mathrm{~mL}$ supernatant was withdrawn and diluted to $10 \mathrm{~mL}$ with PBS. This solution was spectrophotometrically assayed at $272 \mathrm{~nm}$.

\section{Solubility of Meloxicam in the Receptor Phase}

Solubility of MX in PBS was determined by using the method reported in USP XIX. $15 \mathrm{~mL}$ of PBS as the receptor phase was placed in four $25-\mathrm{mL}$ flasks. A quantity of MX was placed in each flask which was greater than the quantity expected to be dissolved in the receptor phase. Flasks were closed tightly and two of them were warmed to $30^{\circ} \mathrm{C}$. All the flasks were placed in a thermostated water bath at $25 \pm 1^{\circ} \mathrm{C}$. The apparatus was maintained under $200 \mathrm{rpm}$ continuous agitation for $24 \mathrm{~h}$. Then, the dispersion formed was filtered through blue ribbon filter paper $\left(S \& S^{5893}\right)$. A sample was withdrawn from the supernatant and MX content was determined spectrophotometrically at $272 \mathrm{~nm}$ after proper dilution. Solubility of MX calculated from the data obtained.

\section{Diffusion Experiments of Meloxicam in Franz-Type Cells}

Cellulose acetate (CA) membrane (Sartorius $0.45 \mu \mathrm{m}$, Millipore) was used between the two halves of diffusion cells for determination of MX release from the formulations in Table 1. PBS free of air bubles was used as the receptor phase. CA membrane was kept immersed in receptor phase for 1 hour and then, it was carefully placed on top of the receptor compartment in the Franz-type diffusion cell (Çalışkan Cam Teknik, Turkey) in order to ensure that no air bubles were left under the membrane. $1 \mathrm{~g}$ of sample was spread on the membrane surface in the donor compartment to cover. Jacketed diffusion cells was kept at $37 \pm 0.5^{\circ} \mathrm{C}$ by constant water circulation from a thermostated water bath. Receptor phase was stirred by using a magnetic stirrer, Comfort Heto Stir Master. Receptor compartment of the Franz-type diffusion cell was containing $33.2 \mathrm{~mL}$ of receptor phase ensuring $3.14 \mathrm{~cm}^{2}$ release surface.

$1 \mathrm{~mL}$ samples were taken from the receptor phase at hourly for $6 \mathrm{~h}$. The assay was ensured sink condition. The amount of MX released was determined spectrophotometrically at $272 \mathrm{~nm}$ after proper dilution of samples.

Release profiles of MX from the formulations were statistically compared by using one-way ANOVA, followed by Tukey - Kramer Multiple Comparisons Tests.

\section{RESULTS AND DISCUSSION}

\section{Validation of the Spectrophotometric Analysis}

The representative linear equation was $A=a C+b$, where $C$ is the concentration, $A$ the absorbance, $a$ the slope, and $b$ is the intercept. In the current method, the regression equation was $A=37.667 C-0.364$ with $r=0.9990$. Absorption spectra of MX showed $\lambda_{\max }$ at $272 \mathrm{~nm}$

Intra-day and inter-day R.S.D. values obtained by the proposed method were found to be between 0.02-0 \%. Accuracy of the method was also expressed here as R.M.E. which were between 3.5-0 \% as can be seen in Table 2 .

Recovery of MX was found between $99.23 \% \pm 0.93$ and $99.79 \pm 0.33$ by standard addition method.

Constituents in formulations were found not to display absorbance at $272 \mathrm{~nm}$ which was the maximum wavelength for MX, indicating specifity of the method. This meant that the constituent in the formulations did not interfere quantification of MX.

Table 2. Intra-Day and Inter-Day Precision of the Analytical Method

\begin{tabular}{|c|c|c|c|}
\hline $\begin{array}{c}\text { Added Concentration } \\
\left(\boldsymbol{\mu g} \mathbf{~ m L}^{-1}\right)\end{array}$ & $\begin{array}{c}\text { Found Concentration } \\
\left(\boldsymbol{\mu g} \mathbf{~ m L}^{-1}\right)\end{array}$ & $\begin{array}{c}\text { R.M.E. } \\
(\mathbf{\%})\end{array}$ & $\begin{array}{c}\text { R.S.D. } \\
\mathbf{( \% )}\end{array}$ \\
\hline \hline \multicolumn{4}{|l}{ Intra-Day } \\
\hline 2.0 & 1.93 & 3.5 & 0.01 \\
4.0 & 4.04 & 1 & 0.02 \\
6.0 & 6.00 & 0 & 0 \\
\hline Inter-Day & 1.93 & 3.5 & 0.01 \\
\hline 2.0 & 4.01 & 0.25 & 0.01 \\
4.0 & 6.00 & 0 & 0.01 \\
6.0 & \multicolumn{5}{|l}{} \\
\hline
\end{tabular}

\section{Solubility of Meloxicam in the Receptor Phase}

MX has a poor water solubility about $0.012 \mathrm{mg} / \mathrm{mL}$ [15]; the solubility increases with increase in $\mathrm{pH}$ value. In this study, solubility of MX in phosphate buffer solution at $\mathrm{pH}$ 7.4 (PBS), the receptor phase was found as $0.75 \pm 0.011$ $\mathrm{mg} / \mathrm{mL}$.

\section{Release of Meloxicam from Formulations in the Franz- type Diffusion Cells}

As can be seen from Fig. (1), when comparing different vehicles, it was found that gel formulation gave the highest release with a significant difference followed by $\mathrm{W} / \mathrm{O} / \mathrm{W}$, $\mathrm{O} / \mathrm{W}, \mathrm{W} / \mathrm{O} / \mathrm{W}-\mathrm{C}$ and $\mathrm{W} / \mathrm{O}$ emulsions, respectively (Table 3 ).

Release rate of MX from gel was $184.83 \mathrm{mcg} / \mathrm{cm}^{2} / \mathrm{h}$ followed by the other formulations as $44,29.83,18.66$ and $8.66 \mathrm{mcg} / \mathrm{cm}^{2} / \mathrm{h}$, respectively. Lipophilic nature of a drug strongly defines its affinity to its vehicle formulation [16]. MX has a good solubility in lipophilic phase in order to the high value of partition coefficient $(\log P=1.9$, in octanolwater) [17]. In general, while the content of lipophilic ingredients in the vehicle increases, release of a lipophilic 
drug decreases compared to a hydrophilic drug. Because of this reason, release rate of $\mathrm{MX}$ was higher from gel formulation. MX sodium salt is an alternative form since MX has a poor aqueous solubility and wettability leading to difficulties in the design of pharmaceutical formulations with high water content. In a recent study, sodium salt of MX was incorporated into gel formulations and its in vivo absorption was studied in rats. The results showed that the bioavailability (\%) of MX sodium gel through transdermal absorption was about $50.1 \%$ by using penetration enhancers [18]. However, sodium salt of MX was thought to be hygroscopic leading difficulties during production. Low solubility in water leads low hygroscopicity.

Viscosity of the vehicle may be another factor that affects release of drug since it may reduce diffusion rate of drug from the vehicle. Hereby, a reverse relationship was observed between viscosity of formulations and rate of MX release. Viscosity of $\mathrm{W} / \mathrm{O}$ emulsion was the highest in all formulations as can be seen in Table 4. Carbopol incorporation into $\mathrm{W} / \mathrm{O} / \mathrm{W}$ emulsion slightly increased the viscosity. Gel formulation had the lowest viscosity as could be expected.

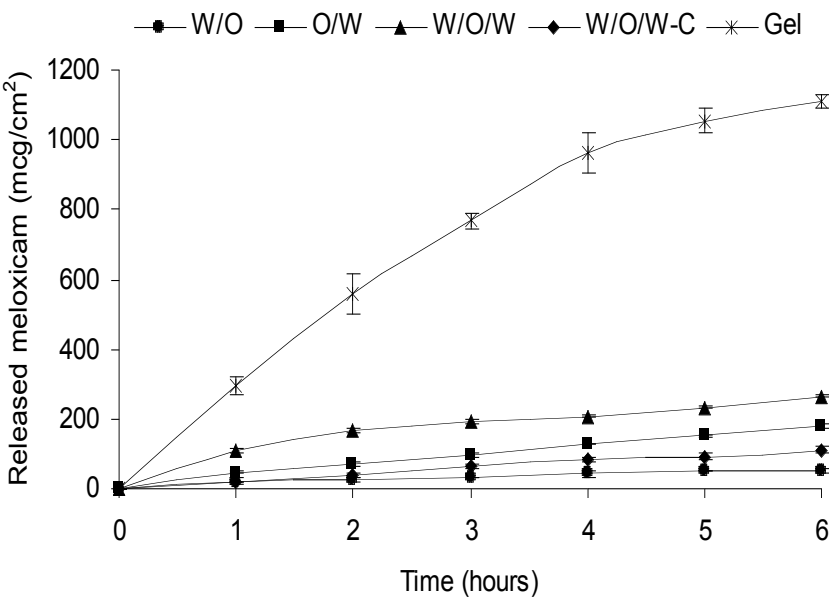

Fig. (1). Release profiles of meloxicam incorporated in different formulations.

Table 3. Statistical Comparison of Release Profiles from Formulations by Using One-Way ANOVA, Followed by Tukey - Kramer Multiple Comparison Tests

\begin{tabular}{|cl|cc|}
\hline \multicolumn{4}{|c|}{ Formulation } \\
\hline \hline W/O Emulsion $\boldsymbol{v s .}$ & & W/O/W Emulsion $\boldsymbol{v s .}$ \\
$\mathrm{O} / \mathrm{W}$ & $\mathrm{p}<0.05$ & $\mathrm{~W} / \mathrm{O} / \mathrm{W}-\mathrm{C}$ & $\mathrm{p}<0.05$ \\
$\mathrm{~W} / \mathrm{O} / \mathrm{W}$ & $\mathrm{p}<0.05$ & $\mathrm{Gel}$ & $\mathrm{p}<0.001$ \\
$\mathrm{~W} / \mathrm{O} / \mathrm{W}-\mathrm{C}$ & $\mathrm{p}<0.05$ & & \\
Gel & $\mathrm{p}<0.001$ & & $\mathrm{p}<0.001$ \\
\hline O/W Emulsion $\boldsymbol{v s}$. & & W/O/W-C Emulsion $\boldsymbol{v s .}$ \\
W/O/W & $\mathrm{p}<0.05$ & Gel & \\
W/O/W-C & $\mathrm{p}<0.05$ & & \\
Gel & $\mathrm{p}<0.001$ & & \\
\hline
\end{tabular}

Release of MX from formulations was kinetically evaluated (Table 5). Diffusion rate of drugs generally depends on the physical structure of the polymer network and its chemical structure in a gel system. Diffusion occurs through the pores if the gel is highly hydrated can be seen as in this case. The fractional release $F$ of drug from at time $t$ was reported to be expressed in general as,

$$
F=\frac{M_{t-}}{M_{0}}=k t^{n}
$$

where $M_{t}$ is the drug amount released at time $t, M_{0}$ is the initial amount of drug, $k$ is the rate constant, and $n$ is a constant called the diffusional exponent. When $n=0, t^{n}=1$ and release $F$ is of zero order; if $n=0.5$, Fick's law holds and the release is represented by Higuchi order (square root equation). Values of $n$ greater than 0.5 indicate anomalous diffusion, especially in swellable polymeric systems [19]. Drug release model from gel was observed to fit to zero order equation $\left(r^{2}=0.9917\right)$ up to the 4 th hour that steady state took place in drug release, then it was closer to Higuchi equation up to the 6th hour. Therefore, drug release mechanism could not be explained since diffusion of drug from polymeric systems like Carbopol ${ }^{\circledR} 934$ gel may deviate from Fickian equation, then follows a non-Fickian (anomalous) behaviour. However, other release profiles displayed best fitted models in Table $\mathbf{6}$ up to each hour.

Table 4. Relationship Between Viscosity of Formulation (Mean \pm S.D., $n=3$ ) and Amount of MX Released After 6 Hours $\left(\mathrm{mcg} / \mathrm{cm}^{2}\right)$

\begin{tabular}{|c|c|c|}
\hline Formulation & $\begin{array}{c}\text { Viscosity } \\
(\mathbf{c P})\end{array}$ & $\begin{array}{c}\text { Amount of MX Released } \\
\left(\mathbf{m c g} / \mathbf{c m}^{2}\right)\end{array}$ \\
\hline \hline $\mathrm{W} / \mathrm{O}$ & $53633 \pm 709$ & $52 \pm 5.89$ \\
$\mathrm{O} / \mathrm{W}$ & $31650 \pm 1104$ & $179 \pm 5.46$ \\
$\mathrm{~W} / \mathrm{O} / \mathrm{W}$ & $20208 \pm 647$ & $264 \pm 3.31$ \\
$\mathrm{~W} / \mathrm{O} / \mathrm{W}-\mathrm{C}$ & $41138 \pm 248$ & $112 \pm 7.15$ \\
Gel & $19503 \pm 190$ & $1109 \pm 19.4$ \\
\hline
\end{tabular}

Table 5. Release Kinetics of Drug from Formulations. Best Fits were Bolded Indicating the Kinetic Model

\begin{tabular}{|l|c|c|c|}
\hline \multirow{2}{*}{ Formulation } & \multicolumn{3}{|c|}{ Determination Coefficient $\left(\mathbf{r}^{2}\right)$} \\
\cline { 2 - 4 } & Zero Order & First Order & Higuchi Order \\
\hline \hline W/O & 0.9730 & 0.9333 & $\mathbf{0 . 9 7 4 3}$ \\
O/W & $\mathbf{0 . 9 5 3 6}$ & 0.9220 & 0.9380 \\
W/O/W & 0.9788 & 0.8934 & $\mathbf{0 . 9 8 0 2}$ \\
W/O/W-C & $\mathbf{0 . 9 7 1 5}$ & 0.9022 & 0.9700 \\
Gel & 0.8485 & 0.8715 & $\mathbf{0 . 9 8 3 0}$ \\
\hline
\end{tabular}

\section{CONCLUSION}

The current study presents a simple, inexpensive, precise and accurate method for determination of MX in multicomponent pharmaceutical preparations. This method was shown advantageous over colormetric methods since it surpassed their sensitivity. R.S.D. of the present method displayed a very suitable determination approach for MX release from dosage forms. 
It could be concluded that the best vehicle for topical formulation of meloxicam was hydrogel among vehicles prepared for this study. It was also concluded that the use of artificial membranes for modelling release of drug, provided a great prediction on its availability and development of the most suitable vehicle for topical use. The studies will be carried out with the same vehicles to assess to percutaneous absorption of meloxicam through skin as the next step.

\section{FUNDING AND ACKNOWLEDGEMENT}

Poster presentation of a part of the present work was performed in Controlled Release Society 31st Annual Meeting and Exposition, Honolulu, Hawaii/ABD in 12-16 June 2004. We were supported by the Research Fund of Istanbul University. Project No UDP-285/29042004.

\section{REFERENCES}

[1] Baboota, S.; Agarwal, S.P. Meloxicam complexation with betacyclodextrin: influence on the anti-inflammatory and ulcerogenic activity. Pharmazie, 2003, 58, 73-74.

[2] Lanas, A.; Sopeña, F. Nonsteroidal anti-inflammatory drugs and lower gastrointestinal complications. Gastroenterol. Clin. North Am., 2009, 38, 333-352.

[3] WHO Drug Information, Anonymous. WHO Drug Information. In Meloxicam safety similar to other NSAID's; World Helath Organization: Geneva, 1998, Vol. 12, p. 147.

[4] Cordero, J.A.; Alarcon, E.; Escribano, R.; Obach, J.; Domenech, A. A comparative study of the transdermal penetration of a series of NSAIDs. J. Pharm. Sci., 1997, 86, 503-508.

[5] Gwak, H.S.; Chun, I.K. Effect of vehicles and penetration enhancers on the in vitro percutaneous absorption of tenoxicam through hairless mouse skin. Int. J. Pharm., 2002, 236, 57-64.

[6] Yener, G.; Gönüllü, Ü.; Üner, M.; Değim, T.; Araman, A. Effect of vehicles and penetration enhancers on the in vitro percutaneous absorption of celecoxib through human skin. Pharmazie, 2003, 58, 330-333.

[7] O’Hanlon, J.J.; Mc Cleane, G.; Muldoon, T. Preoperative application of piroxicam gel compared to a local anaesthetic field block for postoperative analgesia. Acta Anaesthesiol. Scand., 1996, 40, 715-718.

[8] Wilgus, T.A.; Ross, M.S.; Parrett, M.L.; Oberyszy, T.M. Topical application of a selective cyclooxygenase inhibitor suppresses UVB mediated cutaneous inflammation. Prostaglandins Other Lipid Mediat., 2000, 62, 367-370.

[9] Bronaugh, R.L.; Maibach, H.I.; Eds. In vitro release from semisolid dosage forms-What is its value? In: Percutaneous absorption Drugs-Cosmetics-Mechanisms-Methodology; $4^{\text {th }}$ ed. Taylor and Francis Group: USA, 2005, pp. 473-480.

[10] Mura, P.; Faucci, M.T.; Bramanti, G.; Corti, P. Evaluation of transcutol as a clonazepam transdermal permeation enhancer from hydrophilic gel formulations. Eur. J. Pharm. Sci., 2000, 9, 365-372.

[11] Mura, P.; Nassini, C.; Proietti, D.; Manderioli, A.; Corti, P. Influence of vehicle composition variations on the in vitro and ex vivo clonazepam diffusion from hydrophilic ointment bases. Pharm. Acta Helv., 1996, 71, 147-154.

[12] Loftsson, T.; Konrádsdóttir, F.; Másson, M. Development and evaluation of an artificial membrane for determination of drug availability. Int. J. Pharm., 2006, 326, 60-68.

[13] Dal, Ö. Meloksikam içeren topikal formülasyonlar üzerine araştırmalar; M.Sc. Thesis, Istanbul University: Turkey 2004.

[14] Tatar Ulu, S. A new spectrophotometric method for the determination of finasteride tablets. Spectrochim. Acta Part A, 2007, 67, 778-783.

[15] Vijaya Kumar, S.G.; Mishra, D.N. Preparation and evaluation of solid dispersion of meloxicam with skimmed milk. Yakugaku Zasshi, 2006, 126, 93-97.

[16] Hung, C.-F.; Fang, C.-L.; Liao, M.-H.; Fang, J.-Y. The effect of oil components on the physicochemical properties and drug delivery of emulsions: Tocol emulsion versus lipid emulsion. Int. J. Pharm., 2007, 335, 193-202.

[17] Jantharaprapap, R.; Stagni, G. Effects of penetration enhancers on in vitro permeability of meloxicam gels. Int. J. Pharm., 2007, 343, 26-33.

[18] Chang, J.-S.; Huang, Y.-B.; Hou, S.-S.; Wang, R.-J., Wu, P.-C.; Tsai, Y.-H. Formulation optimization of meloxicam sodium gel using response surface methodology. Int. J. Pharm., 2007, 338, 4854.

[19] Martin, A. Ed. In: Physical Pharmacy. Physical Chemical Principles in the Pharmaceutical Sciences; $4^{\text {th }}$ ed., Lea and Febiger: USA, 1993. 